DZIEJE NAJNOWSZE, ROCZNIK XLVII - 2015, 2

PL ISSN 0419-8824

Jacek Pietrzak

Łódź

\title{
„Wyeliminowanie z szeregów elementu uciążliwego i niebezpiecznego". Sprawa Obozu Dyscyplinarnego Armii Polskiej na Wschodzie w Latrun w Palestynie (1944-1945)
}

Obozy odosobnienia tworzone podczas drugiej wojny światowej w ramach Polskich Sił Zbrojnych kojarzą się przede wszystkim z ośrodkami w Cerizay we Francji i w Rothesay (wyspa Bute, „Wyspa Węży”) w Wielkiej Brytanii, gdzie w latach 1939-1942 izolowano oficerów związanych przed wojną z „reżimem sanacyjnym” lub za takich uznawanych" Niemal zupełnie nieznany epizod stanowią natomiast podjęte w Armii Polskiej na Wschodzie (APW) działania mające na celu izolację żołnierzy (a także uchodźców cywilnych) oskarżanych o działalność komunistyczną i prosowiecką (w tym także wcześniejszą kolaborację z Sowietami) oraz uznawanych za niebezpiecznych przestępców pospolitych. Próba rozwiązania tego problemu w postaci zorganizowania obozu izolacyjnego na terenie Palestyny okazała się zagadnieniem delikatnym i skomplikowanym, prowadząc do stawiania istotnych pytań o granice ograniczania swobód obywatelskich w warunkach wojennych.

W sierpniu i wrześniu 1943 r. APW została przetransportowana z Iraku do Palestyny w związku z przygotowaniami do planowanego użycia wydzielonego z armii 2 Korpusu na froncie śródziemnomorskim. Największa polska formacja lądowa znalazła się na obszarze brytyjskiego obszaru mandatowego.

W listopadzie 1943 r. wizytujący APW Naczelny Wódz gen. Kazimierz Sosnkowski rozkazał dowódcy armii gen. Władysław Andersowi utworzenie spośród żołnierzy podejrzewanych o sympatie prosowieckie specjalnych wydzielonych oddziałów roboczych, które miały następnie zostać przekazane pod kontrolę władzom brytyjskim ${ }^{2}$. Pomysł ten nie uzyskał jednak akceptacji Brytyjczyków. Przedstawiciele kontrwywiadu MI 5 podkreślali zarówno brak podstaw prawnych takiego rozwiązania, jak i obawy przed negatywnymi reakcjami polityków i prasy. Zbliżone stanowisko wyrażał minister obrony narodowej gen. Marian Kukiel, który

\footnotetext{
${ }^{1}$ Zob. szerzej: M. Dymarski, Polskie obozy odosobnienia we Francji $i$ wielkiej Brytanii w latach 1939-1942, „Dzieje Najnowsze” 1997, r. XXVIII, nr 3, s. 113-127; J. Zuziak, Obozy izolacyjne Rothesay i Tignabruaich. Z historii Polskich Sit Zbrojnych w Wielkiej Brytanii, „Mars” 1995, t. III, s. 75-90. ${ }_{2}$ Instytut Polski i Muzeum im. gen. Sikorskiego [dalej: IPMS], kol. 138/213 Pismo NN do premiera S. Mikołajczyka, b.d. [1944]; IPMS, kol. 138/213, Notatka urzędowa w sprawie utworzenia obozu odosobnienia w Latrun, b.d.
} 
wskazywał, że tego typu działania mogłyby zostać uznane za represje polityczne i posłużyć jako argument propagandowy dla „,czynników uważających armię polską za ośrodek reakcji”. Minister podkreślał: „Przeżywana sytuacja polityczna zaleca jak najdalej idącą ostrożność $\mathrm{w}$ traktowaniu problemów związanych z zagadnieniem sowieckim. Zwłaszcza traktowanie żołnierzy uchodzących za nastawionych prosowiecko unikać musi nawet pozorów prześladowania jak długo nie przejawią oni akcji niebezpiecznej dla całości lub spoistości Armii"’3.

Warto zauważyć, że we wrześniu i październiku 1943 r. w wyniku działań kontrwywiadu i żandarmerii APW dokonano aresztowań w grupie oficerów i żołnierzy określanej jako „berlingowcy" ${ }^{4}$. Niepokój budziła jednak nie tylko prosowiecka działalność polityczna, lecz także narastający problem przestępczości pospolitej. Chodziło zwłaszcza o grupę kilkudziesięciu „kryminalistów” (skazywanych przed wojną na wysokie wyroki), zwolnionych wcześniej z szeregów $\mathrm{APW}^{5}$.

Co ciekawe, strona brytyjska, wyrażająca tak zdecydowane obawy przed tworzeniem „oddziałów roboczych”, miała wyraźnie sugerować polskiemu dowództwu utworzenie obozu dla internowanych ${ }^{6}$. Podczas konferencji z udziałem przedstawicieli dowództwa APW oraz polskich władz cywilnych na Bliskim Wschodzie, która odbyła się 5 i 6 XII 1943 r. w Kairze, gen. Michał Tokarzewski-Karaszewicz, zastępca dowódcy armii, oficjalnie przedstawił propozycję utworzenia obozu, do którego miały trafiać osoby o przeszłości przestępczej zwolnione z szeregów wojska. Ostatecznie w rezultacie dyskusji uznano, że „zdeklarowani przestępcy", jak określono osoby, wobec których zasądzono przed wojną w Polsce wysokie wyroki, powinni zostać umieszczeni w aresztach wojskowych. Postanowiono także powołać specjalne komisje prawne dla oceny osób podejrzanych o działalność przestępczą, a przede wszystkim skierować do władz brytyjskich wniosek o zgodę na umieszczanie osób uznawanych za szczególnie niebezpieczne w brytyjskich więzieniach lub obozach dla internowanych ${ }^{7}$.

Chociaż ustalenia konferencji nie wskazywały jasno zamiaru utworzenia obozu odosobnienia, gen. Tokarzewski-Karaszewicz przystąpił do działania. Podkreślał później, że koncepcja obozu powstała w rezultacie ,sugestii” strony brytyjskiej, a zarazem stwierdzał, że jego cel to: ,[...] wyeliminowanie z szeregów z chwilą wejścia do akcji [2 Korpusu — J. P.]

${ }^{3}$ IPMS, kol. 138/213, Pismo gen. M. Kukiela do gen. K. Sosnkowskiego w sprawie „eliminacji żołnierzy podejrzanych o kontakty z NKWD” z 22 I 1944 r.

${ }^{4}$ Chodzi o tzw. grupę kpt. Kazimierza Rosena-Zawadzkiego, której członkowie byli sądzeni przez sąd APW (14 -18 II 1944). Członkowie grupy, z wyjątkiem Zawadzkiego przedwojenni komuniści, podjęli współpracę z Sowietami w obozach jenieckich lub pod okupacją sowiecką. Proces grupy posłużył propagandzie sowieckiej do ostrych ataków na armię gen. Andersa. Szerzej zob. J. Pietrzak, Polscy uchodźcy na Bliskim Wschodzie w latach drugiej wojny światowej. Ośrodki, instytucje, organizacje, Łódź 2012, s. 390-393.

${ }^{5}$ Osoby, o których mowa, zostały zwolnione z APW jeszcze w Iraku, a następnie skierowane do cywilnego ośrodka uchodźczego w Ahwazie (Iran). „Kryminaliści” mieli dokonywać tam czynów o charakterze chuligańskim. Zostali następnie przewiezieni do Palestyny i umieszczeni w więzieniu wojskowym, jednak niebawem zwolniono ich jako cywilów. IPMS, Prezydium Rady Ministrów [dalej PRM], t. CXXVII, Wyciąg ze sprawozdania Delegata Ministerstwa Pracy i Opieki Społecznej przy Dowództwie APW Antoniego Pająka za marzec 1944 r., Jerozolima, 10 V 1944 r.

${ }^{6}$ IMPS, kol. 138/213, Notatka urzędowa...

${ }^{7}$ IPMS, A 6/1, Protokół konferencji z 5-6 XII 1943 r. W konferencji brali udział: gen. W. Anders, gen. M. Tokarzewski-Karaszewicz, gen. Józef Wiatr (dowódca Bazy i Etapów APW), Henryk Strasburger (minister-delegat rządu do spraw polskich na Wschodzie), płk dypl. Antoni Szymański (szef Wydziału Wojskowego urzędu ministra-delegata), Julian Maliniak (szef Wydziału Opieki Społecznej urzędu ministra-delegata), Jan Tabaczyński (szef Centrum Informacji na Wschodzie w Jerozolimie). 
elementu uciążliwego i niebezpiecznego ze względu na przestępczość polityczną i kryminalną. Element ten wywierał szkodliwy wpływ na otoczenie i podrywał morale i dyscyplinę wojska" ${ }^{\text {. }}$ W innym dokumencie obok prewencyjnego charakteru placówki podkreślano ,potrzebę zastosowania do osób w obozie osadzonych pewnych metod wychowawczych, dostępnych w polowych warunkach obozowych"9.

23 XII 1943 r. zastępca dowódcy APW wydał rozkaz utworzenia z dniem 1 I 1944 r. „Obozu Dyscyplinarnego”, który miał zostać zlokalizowany w palestyńskiej miejscowości Latrun (koło miasta Ramla), w wydzielonych sektorach brytyjskiego obozu dla internowanych Camp $321^{10}$. W obozie mogli zostać osadzeni żołnierze APW zarówno w służbie czynnej, jak i w stanie nieczynnym, czasowo urlopowani, a nawet uznani za trwale niezdolnych do służby (kategoria „E”), ,pozostawanie których na wolności, ze względu na ich działalność przestępczą natury politycznej, moralnej czy też kryminalnej — podważałoby morale i dyscyplinę wojska" ${ }^{\prime 1}$. Decyzję o umieszczeniu w obozie formalnie podejmował dowódca APW, jednak wobec wyjazdu gen. Andersa na front włoski kompetencje te należały do jego zastępcy, czyli gen. Tokarzewskiego. W obozie można było zostać osadzonym na czas ,ściśle określony", do odwołania zarządzenia o skierowaniu do obozu lub do czasu demobilizacji PSZ po zakończeniu wojny. Przewidywano indywidualne kary dyscyplinarne, takie jak gorsze wyżywienie, wstrzymanie widzeń, korespondencji oraz możliwości korzystania z gazet i książek, a także kary zbiorowe, np. karne apele i ćwiczenia. Osadzeni mieli podczas pobytu w obozie uczestniczyć w szkoleniu wojskowym ${ }^{12}$. Ze względu na lokalizację obozu jego zewnętrzne zabezpieczenie miały zapewnić władze brytyjskie ${ }^{13}$.

Obóz miał podlegać dowódcy Jednostek Terytorialnych na Środkowym Wschodzie (był nim wówczas płk Bolesław Ostrowski), a pod względem gospodarczym przydzielono go do Komendy Placu w Jerozolimie. Struktura obozu miała obejmować komendę oraz trzy kompanie: „specjalną”, „przejściową” oraz „karną”. Niebawem strukturę obozu zmodyfikowano, tworząc izolowane od siebie ,rejony”: administracyjny (komenda obozu), oficerski (dla osadzonych oficerów), karny (dla szeregowych podejrzewanych o „skłonności natury kryminalnej”), specjalny (dla szeregowych z zarzutami o przestępczość polityczną). Zwracano szczególną uwagę na konieczność uniemożliwienia jakichkolwiek kontaktów między grupą

\footnotetext{
${ }^{8}$ IPMS, kol. 138/213, Depesza gen. M. Tokarzewskiego-Karaszewicza do gen. M. Kukiela z 24 I $1944 \mathrm{r}$.

9 Ibidem, Rozkaz organizacyjny Obozu Dyscyplinarnego w Latrun podpisany przez gen. M. Tokarzewskiego-Karaszewicza z 20 III 1944 r.

${ }^{10}$ Ibidem, Zarządzenie gen. M. Tokarzewskiego-Karaszewicza z 23 XII 1943 r. W brytyjskim obozie przebywało kilkunastu obywateli polskich, m.in. podejrzewanych o współpracę z wywiadem niemieckim. Byli wśród nich m.in. zamieszani w głośną aferę Samsona Mikicińskiego dziennikarz Bronisław Syrokomla-Stefanowski oraz przemysłowiec Wiktor Kutten. Zob.: IPMS, A 49/176 (korespondencja konsulatu generalnego w Tel Awiwie dotycząca więźniów); Polsko-brytyjska wspótpraca wywiadowcza podczas II wojny światowej, t. II, Wybór dokumentów, oprac. J. S. Ciechanowski, Warszawa 2005, s. 143-145. Warto dodać, że po doświadczeniach powstania arabskiego (1936-1939) w pobliżu Latrun Brytyjczycy wybudowali w latach 1941-1942 ważny strategicznie fort Tegart. Wieś Latrun obecnie nie istnieje, została zniszczona podczas wojny izraelsko-arabskiej w $1948 \mathrm{r}$.

${ }^{11}$ IPMS, kol. 138/213, Rozkaz organizacyjny z 20 III 1944 r.

12 Ibidem oraz zał. nr 2 do zarządzenia z 23 XII 1943 r. Wytyczne dla Komendanta Obozu Dyscyplinarnego w Latrun, b.d.

${ }^{13} \mathrm{~W}$ czasie funkcjonowania obozu stwierdzono jednak, że brytyjskie oddziały wartownicze nie spełniły swojej roli, gdyż ich żołnierze podejmowali kontakty z osadzonymi. W tej sytuacji do strzeżenia polskiej części obozu wyznaczono 8 kompanię wartowniczą APW. IPMS, kol. 329/18, Zał. do pisma gen. M. Tokarzewskiego-Karaszewicza do gen. W. Andersa z 18 III 1944 r.
} 
więźniów „,politycznych” i „kryminalnych”. Komendant obozu miał posiadać uprawnienia dyscyplinarne równe dowódcy pułku. W zakresie bezpieczeństwa w obozie wspomagał go oficer informacyjny, mający prowadzić kontrolę korespondencji i widzeń, a także inwigilację więźniów z wykorzystaniem informatorów spośród osadzonych. Do jego obowiązków należało także prowadzenie dochodzeń oraz przeciwdziałanie kontaktom internowanych ze światem zewnętrznym oraz między wydzielonymi grupami. Przewidywano, że załoga obozu będzie liczyła trzydzieści dziewięć osób, w tym ośmiu oficerów, szesnastu podoficerów i piętnastu szeregowych. Zakładano jednak także obsadzanie części funkcji dowódczych w obozie przez internowanych oficerów i podoficerów; według rozkazu organizacyjnego do pełnienia tej roli należało ,dobierać element pod względem moralnym i wyszkoleniowym bardziej energiczny i rokujący nadzieję poprawy”. Jednak wytyczne dla komendanta obozu precyzowały już, że ,,celem stworzenia rękojmi należytego utrzymania dyscypliny, karności, posłuszeństwa i bezpieczeństwa obozu" internowani obejmujący stanowiska dowódcze w grupie „politycznej” mieli się rekrutować z grupy „kryminalnej” ${ }^{14}$. Ten pomysł nie tylko stał w sprzeczności z założeniem ścisłej izolacji osadzonych ,politycznych” od „kryminalnych", lecz także wywoływał naturalne opory moralne. Zastępca szefa Oddziału II Sztabu Naczelnego Wodza płk dypl. Tadeusz Skinder stwierdził nawet, że rozwiązanie to ,,jest niezgodne z naszym duchem i niegodne naszych tradycji”, ${ }^{\prime 5}$.

Ostatecznie obóz powstał 11 stycznia. Do osadzenia w nim zakwalifikowano 156 żołnierzy, w tym 14 oficerów ${ }^{16}$. Według danych z marca w obozie przebywało 74 żołnierzy, w tym 13 oficerów i 23 szeregowych pod zarzutem „wrogiej działalności politycznej” oraz 38 szeregowych za przestępstwa o charakterze pospolitym. W obozie, wbrew jego wojskowemu charakterowi, umieszczono także około 50 cywilów, byłych żołnierzy APW zwolnionych z wojska i oskarżanych przez władze brytyjskie o różne przestępstwa pospolite na terenie Palestyny $^{17}$. Dokumenty różnią się, jeśli chodzi o ostateczną liczbę internowanych w Latrun; można założyć, że przebywało tam przynajmniej 214 osób, a prawdopodobnie nawet ponad $260^{18}$. Pierwszym komendantem obozu był kpt. Zygmunt Łuszczyński, były oficer Policji Państwowej ${ }^{19}$.

${ }^{14}$ Ibidem, kol. 138/213, Zarządzenie z 23 XII 1943 r. oraz zał. nr 1(tymczasowy etat Komendy Obozu Dyscyplinarnego), nr 2 (Wytyczne); Rozkaz organizacyjny z 20 III 1944 r.

${ }^{15}$ Ibidem, Pismo płk. dypl. T. Skindera do szefa Służby Sprawiedliwości WP z 28 III 1944 r.

${ }^{16}$ Ibidem, Depesza gen. M. Tokarzewskiego-Karaszewicza do gen. M. Kukiela z 24 I 1944 r.

${ }^{17}$ Ibidem, kol. 329/18, Zał. do pisma gen. M. Tokarzewskiego-Karaszewicza do gen. W. Andersa z 18 III 1944 r.; ibidem, kol. 138/213, Depesza gen. M. Tokarzewskiego do gen. K. Sosnkowskiego z 26 II 1944 r. Sprawa liczby osadzonych cywilów nie była jednak jasna. W Londynie wskazywano na brak danych. Ibidem, Notatka urzędowa...

${ }^{18}$ Powyższa liczba wynika $\mathrm{z}$ danych przytoczonych przez gen. J. Wiatra w okresie likwidacji obozu. Wymienia on łącznie 201 szeregowych i podoficerów, do których należy dodać 13 oficerów. Prawdopodobnie liczba ta nie uwzględnia jednak grupy „cywilnej” (prawdopodobnie ok. 50 osób). Zob. ibidem, Depesza gen. J. Wiatra dla gen. M. Kukiela z 17 VII 1944 r.; Wyciąg z meldunku Oddziału II Sztabu APW z 20 IV 1944 r. (tu informacja o oficerach).

${ }^{19}$ Ibidem, Pismo gen. M. Tokarzewskiego-Karaszewicza do płk. B. Ostrowskiego z 7 IV 1944 r. Kpt. Z. Łuszczyński, komisarz PP, był przed wojną szefem Urzędu Śledczego przy Komendzie Wojewódzkiej PP w Brześciu. Więziony przez Sowietów, m.in. w obozie w Griazowcu. W PSZ w ZSRR został szefem Oddziału II 6 Dywizji Piechoty; następnie kierował placówką Oddziału II APW w Teheranie. Komendantem obozu przestał być w drugiej połowie lutego. Został następnie szefem Wydziału Informacyjnego Sztabu Jednostek Wojska na Środkowym Wschodzie (3 Korpusu). Z pisma Tokarzewskiego może wynikać, że jego następcą został kpt. Bolesław Mościcki, wcześniej w Rejonie Etapów w Iranie. 
Wśród trzynastu izolowanych oficerów było pięć osób, które w niewoli sowieckiej zdecydowały się na współpracę z władzami sowieckimi i trafiły do osławionego ośrodka NKWD w Małachówce pod Moskwą (,willa szczęścia”). Byli to: ppłk Kazimierz Dudziński, ppłk Marian Morawski, ppłk Leon Tyszyński, por. Włodzimierz Szumigalski, por. Michał Tomala $^{20}$. Pozostałym ośmiu oficerom zarzucano współpracę z NKWD podczas okupacji lub pobytu w niewoli sowieckiej, ewentualnie agitację komunistyczną i prosowiecką ${ }^{21}$. Do obozu trafili również dwaj żołnierze sądzeni w głośnym procesie grupy „berlingowców” w lutym 1944 r. (jako jedyni z tej grupy nie zostali wówczas skazani). Byli to przedwojenni działacze Komunistycznej Partii Polski (KPP): kpr. pchor. Romuald Gadomski ${ }^{22}$ oraz st. sierżant Tadeusz Ludwik Strzałkowski ${ }^{23}$.

Utworzenie obozu niemal od początku wywoływało kontrowersje. Na początku lutego Naczelny Wódz polecił jego likwidację i powołanie w jego miejsce specjalnej kompanii pionierów (saperów), odizolowanej od pozostałych oddziałów armii. Sosnkowski niejako powracał zatem do pierwotnej koncepcji oddziałów roboczych. W depeszy do gen. Andersa pisał: „Obozy dyscyplinarne dla osób wojskowych nie skazanych sądownie ani nie odsiadujących kar dyscyplinarnych, wywołają wrogą akcję w opinii polskiej i obcej. Okoliczność, że $\mathrm{w}$ danym wypadku były sugestie władz brytyjskich nie zapobiegnie kampanii w prasie brytyjskiej i poruszeniu sprawy w parlamencie" ${ }^{24}$.

Pomimo stanowiska Naczelnego Wodza gen. Tokarzewski zdecydowanie opowiadał się utrzymaniem obozu. Podkreślał konieczność izolowania osób, które popełniły przestępstwa w Polsce przed wybuchem wojny lub podczas pobytu w obozach sowieckich (w tym ostatnim przypadku chodziło o podjęcie w niewoli współpracy z Sowietami). Tokarzewski wskazywał, że chodzi o osoby, które nie podlegają jurysdykcji polskich sądów wojskowych ze względu na nieotrzymanie powołania w 1939 r., a także umowę polsko-brytyjską pozwalającą sądzić

${ }^{20}$ Ibidem, Wyciąg z meldunku z 20 IV 1944 r. Szerzej na temat Małachówki i wspomnianych oficerów zob.: S. Jaczyński, Ocaleni od zagłady. Losy oficerów polskich ocalatych z masakry katyńskiej, Warszawa 2012 , s. $245-277$.

${ }^{21}$ IPMS, kol. 138/213, Wyciąg z meldunku z 20 IV 1944 r. W grupie tej był jeden kapitan, dwóch poruczników, pięciu podporuczników.

${ }^{22}$ Romuald Gadomski był działaczem KPRP/KPP od 1922 r.; działał także w jej „przybudówkach”: PPS-Lewicy oraz Komunistycznej Partii Zachodniej Ukrainy (sekretarz we Lwowie). W latach 19391941 w redakcji „Sztandaru Wolności” w Mińsku. W 1941 r. na polecenie Kominternu wstąpił do PSZ w ZSRR, w APW należał do prosowieckiej grupy kpt. K. Rosena-Zawadzkiego; został aresztowany we wrześniu 1943 r. Z obozu został zwolniony 11 XII 1944 r. Następnie był czołowym działaczem i sekretarzem ZPP na Środkowym Wschodzie. W latach 1945-1946 delegat Tymczasowego Rządu Jedności Narodowej w Palestynie i Transjordanii. W latach 1946-1949 w Ministerstwie Bezpieczeństwa Publicznego, m.in. zastępca szefa wywiadu zagranicznego. W latach 1950-1954 zastępca szefa i szef Polskiego Radia; następnie redaktor kilku gazet i korespondent zagraniczny PAP. Zob. Archiwum Akt Nowych [dalej: AAN], t. os. 10824; B. Gadomski, Gadomski Romuald (1905-1974), w: Stownik biograficzny działaczy polskiego ruchu robotniczego, red. F. Tych, t. II, Warszawa 1987, s. 163, 164. Zob. też krótką relację Gadomskiego z pobytu w Latrun: AAN, R 156, Działalność lewicowa w armii Andersa, Relacja R. Gadomskiego z 16 XI 1966 r., k. 89-90.

${ }^{23}$ Tadeusz Ludwik Strzałkowski, nauczyciel; żołnierz WP w latach 1918-1921; od 1932 r. działacz KPP, głównie w środowisku nauczycielskim. W latach 1939-1941 sowiecki wizytator szkolny w Białymstoku. W 1941 r. na polecenie Kominternu wstąpił do PSZ w ZSRR; był m.in. oficerem oświatowym w 9 Dywizji Piechoty. Należał do grupy K. Rosena-Zawadzkiego; został aresztowany 29 X 1943 r. Z obozu w Latrun zwolniony 2 I 1945 r. Zmarł w Tel Awiwie. Zob. A. Kochański, Strzałkowski Tadeusz Ludwik (1900-1946), Polski stownik biograficzny, t. XLIV, Warszawa-Kraków 2007, s. 584-586.

${ }^{24}$ IPMS, kol. 138/213, Depesza gen. K. Sosnkowskiego do gen. W. Andersa z 3 II 1944 r. 
tylko za przestępstwa popełnione po sierpniu 1940 r. Zastępca dowódcy APW uważał także, że pozostawanie wspomnianej grupy osób na wolności wzbudzało rozgoryczenie w szeregach armii ${ }^{25}$.

Tokarzewski akcentował znaczenie obozu w neutralizowaniu ,elementu niebezpiecznego politycznie”: „Akcja czynników wrogich na tut.[ejszym] terenie na odcinku propagandy i dywersji skierowanej na Armię Polską i uchodźstwo [...] w chwili obecnej przybiera konkretne formy organizacyjne i planowe. Wymaga ona już obecnie zdecydowanej reakcji. Pozostawienie na wolności groźnego elementu uniemożliwia naszym organom bezpieczeństwa przeciwdziałanie w wykonywaniu [wykorzystywaniu - J. P.] go przez czynniki wrogie w czynnej akcji przeciw Polsce. [...] inna forma reakcji naszej nie tylko nie zapobiegnie akcji wrogiej propagandy, lecz element ten znowu stanie się narzędziem w jej ręku [...]"26.

Nie ulega wątpliwości, że generałowi chodziło przede wszystkim o tworzoną w tym czasie w Palestynie organizację komunistyczną Związek Patriotów Polskich na Środkowym Wschodzie, o której informacje dostarczał kontrwywiad APW ${ }^{27}$. Tokarzewski zdawał sobie jednak sprawę, że ten polityczny aspekt funkcjonowania obozu mógł wywoływać problemy w relacjach z władzami brytyjskimi, oficjalnie nieakceptującymi przeciwdziałania działalności komunistycznej w polskiej armii (jako dyskryminacji za poglądy polityczne) ${ }^{28}$

Tokarzewski próbował także uzasadnić internowanie w Latrun grupy uchodźców cywilnych, wcześniej zwolnionych z wojska. Twierdził, że domagały się tego polskie władze cywilne pod naciskiem brytyjskich władz mandatowych. Sprawa miała dotyczyć osób aresztowanych przez Brytyjczyków za przestępstwa pospolite, np. kradzieże i awantury ${ }^{29}$.

Na początku 1944 r. polskie placówki w Palestynie rzeczywiście były alarmowane doniesieniami o narastającej przestępczości wśród eksżołnierzy. Sprawy te nawet dyskutowano na forum rady miejskiej Tel Awiwu, informowała o nich prasa żydowska, a konsul w tym mieście Henryk Rosmarin miał nawet otrzymać od miejscowej policji prośbę o zgodę na aresztowanie około stu podejrzanych ${ }^{30}$. Z informacji przekazanych przez konsula generalnego w Jerozolimie Aleksego Wdziękońskiego wynikało, że brytyjskie władze policyjne zajęły w tej kwestii ostrożne stanowisko i nie domagały się jednak prewencyjnej izolacji

25 Ibidem, Depesza gen. M. Tokarzewskiego-Karaszewicza do gen. K. Sosnkowskiego z 26 II 1944 r.

26 Ibidem.

${ }^{27}$ Zob. szerzej: J. Pietrzak, Działalność komunistów wśród polskiego wychodźstwa na Bliskim Wschodzie w świetle materiałów kontrwywiadu Polskich Sił Zbrojnych (1944 r.), „Dzieje Najnowsze” 2006, r. XXXVIII, nr 3, s. 119-136; idem, Związek Patriotów Polskich na Środkowym Wschodzie. Nieznana karta działalności komunistów podczas II wojny światowej, w: Lewica polska, t. II Działalność, red. E. Krasucki, T. Sikorski, A. Wątor, Wrocław 2012, s. 63-84.

${ }^{28}$ IPMS, kol. 138/213, Pismo gen. M. Tokarzewskiego-Karaszewicza do płk. B. Ostrowskiego z 7 IV 1944 r. Generał zalecał płk. Ostrowskiemu, by na zapytania władz brytyjskich o przyczyny internowania podkreślał „,naruszenie przepisów na podłożu karno-dyscyplinarnym, w formie ogólnikowo i krótko sformułowanych zarzutów”. Warto zauważyć, że dowództwo brytyjskie podkreślało, że ,samo [...] wyrażanie krańcowych politycznych poglądów nie stwarza podstawy do działania, musi być dowód działalności wywrotowej”. Wskazywano także na „reperkusje polityczne” akcji przeciwko komunistom, ,w szczególności w wypadku gdy osoby te pozostają w styczności z Rosją”. Ibidem, Pismo ppłk. K.W. Jonesa (dowództwo sił brytyjskich na Bliskim Wschodzie) do ppłk. dypl. Wincentego Bąkiewicza, szefa Oddziału II Sztabu APW z 11 X 1943 r.

${ }^{29}$ Ibidem, Depesza gen. M. Tokarzewskiego-Karaszewicza do gen. K. Sosnkowskiego z 26 II 1944 r.

${ }^{30}$ AAN, Mikrofilmy ze zbiorów Instytutu Hoovera, Ministerstwo Spraw Zagranicznych [dalej: HIMSZ], mf 325, Depesza konsula gen. RP w Tel Awiwie H. Rosmarina z 2 II 1944 r.; mf 318, Depesza konsula gen. w Jerozolimie A. Wdziękońskiego dla min. H. Strasburgera z 5 II 1944 r.; mf 175, Notatka o przestępcach w Palestynie, Londyn, 11 II 1944 r. 
przestępców. Sprawa budziła jednak poważny niepokój przedstawicieli rządu RP, konsula Wdziękońskiego i delegata Ministerstwa Pracy i Opieki Społecznej (MPiOS) przy dowództwie APW Antoniego Pająka. W celu uniknięcia problemów prawnych sugerowali oni nawet ponowne wcielenie do armii zwolnionych z wojska przestępców w celu osadzenia ich w obozie w Latrun. Konsul potwierdził także, że gen. Tokarzewski zgodził się na przyjęcie w Latrun cywilów pod warunkiem decyzji odpowiednich polskich władz cywilnych w stosunku do każdego internowanego oraz współdziałania w tych sprawach władz mandatowych ${ }^{31}$. Niewykluczone, iż generał uważał, że Brytyjczycy niejako w „rewanżu” za zgodę strony polskie na izolację cywilów nie będą mieszać się do sprawy przetrzymywania w Latrun osób oskarżanych o aktywność prosowiecką.

3 III 1944 r. minister-delegat rządu do spraw polskich na Wschodzie Henryk Strasburger, biorąc pod uwagę wcześniejszą propozycję Tokarzewskiego, powołał specjalną komisję o charakterze organu opiniodawczego konsula generalnego w Jerozolimie, w której skład weszli delegaci resortów rządowych w Palestynie ${ }^{32}$. Głównym zadaniem komisji było przygotowanie listy obywateli polskich stanowiących zagrożenie dla bezpieczeństwa i porządku publicznego oraz przekazanie ich władzom mandatowym. Osoby, które znalazły się na liście, mogły zostać zakwalifikowane do osadzenia w polskim lub brytyjskim obozie odosobnienia, ewentualnie wnioskowano wobec nich inwigilację i badanie sprawy, a w przypadku chorych specjalną opiekę lekarską. Według strony polskiej władze mandatowe faktycznie zignorowały działania komisji ${ }^{33}$. Z kolei opinia prawna wydana przez polskie władze w Londynie wyraźnie sugerowała ograniczenie aktywności komisji do działań ewidencyjnych i informacyjnych dla potrzeb wewnętrznych oraz ewentualnie konsultowania władz brytyjskich. Podkreślano, że obywatele polscy, którzy naruszyli miejscowe prawo, podlegają w pełni kompetencjom miejscowych władz, które nie mają obowiązku współpracy z polskimi instytucjami, chociaż mogą ją podjąć ze względów kurtuazyjnych ${ }^{34}$.

Kolejne opinie ekspertów rządowych dotyczące komisji były znacznie ostrzejsze, a nawet druzgocące. Jej powołanie i funkcjonowanie uznawano za bezprawne, wskazywano, że zadaniem placówek konsularnych jest opieka nad uchodźcami, a nie działanie na ich niekorzyść wobec władz obcych, nawet jeśli dotyczyło to przestępców. Negatywne stanowisko wobec funkcjonowania komisji zajęły także resorty spraw zagranicznych, sprawiedliwości oraz pracy i opieki społecznej, który wycofał 6 kwietnia swojego przedstawiciela z komisji. W tej sytuacji komisja faktycznie zakończyła oficjalną działalność,

\footnotetext{
${ }^{31}$ AAN, HI-MSZ, mf 175, Pismo konsula A. Wdziękońskiego do min. H. Strasburgera z 28 II 1944 r.

${ }^{32}$ AAN, Ministerstwo Pracy i Opieki Społecznej Rządu Emigracyjnego [dalej: MPiOS], t. XCIX, Pismo H. Strasburgera do A. Wdziękońskiego z 3 III 1944 r., k. 33; IPMS, PRM, t. CXXVII, Wyciąg ze sprawozdania A. Pająka za marzec 1944 r., Jerozolima 10 V 1944. Komisji przewodniczył konsul A. Wdziękoński, a w jej skład weszli delegaci: Ministerstwa Spraw Wewnętrznych (Czesław Andrzejewski), Ministerstwa Sprawiedliwości (Zygmunt Blenau), Ministerstwa Pracy i Opieki Społecznej (Kazimierz Jaroszewski oraz delegat przy dowództwie APW Antoni Pająk), Ministerstwa Obrony Narodowej (ppłk dypl. Leopold Gebel).

${ }^{33}$ Ibidem; AAN, MPiOS, t. XCIX, Pismo A. Wdziękońskiego do sekretarza rządu palestyńskiego (Chief Secretary Government of Palestine) z 30 III 1944 r., k. 87-88; AAN, HI-MSZ, mf 175, Pismo A. Wdziękońskiego do H. Strasburgera z 1 V 1944 r. Zgodnie z wytycznymi min. Strasburgera miało to oznaczać, że sprawa przestępców cywilów zostaje pozostawiona w wyłącznej gestii władz mandatowych.

${ }^{34}$ AAN, HI-MSZ, mf 175, Opinia w sprawie udziału władz polskich w procedurze mierzącej do internowania na terenie Palestyny zwolnionych z A.P. obywateli polskich zagrażających bezpieczeństwu publicznemu, Londyn, 6 IV 1944.
} 
chociaż nadal zbierano materiały dowodowe i kompletowano listy osób zagrażających bezpieczeństwu ${ }^{35}$.

Argumenty wysuwane przez Tokarzewskiego i przedstawicieli władz cywilnych na Bliskim Wschodzie nie spotkały się ze zrozumieniem w Londynie. Naczelny Wódz przekazał sprawę ministrowi obrony narodowej gen. Kukielowi. Opinia przygotowana w tej sprawie przez szefa Sądownictwa Wojskowego płk. Kazimierza Słowikowskiego była jednoznacznie negatywna. Stwierdzono w niej brak podstaw prawnych pozwalających na tworzenie w PSZ „obozów dyscyplinarnych” i stanowczo podkreślono, że władze wojskowe nie mają uprawnień do izolowania osób cywilnych. Konkluzja opinii była zgodna z wcześniejszymi koncepcjami Sosnkowskiego. Szef wojskowego wymiaru sprawiedliwości proponował utworzenie odrębnego pododdziału saperskiego lub nawet przydzielenie „,niebezpiecznych” żołnierzy do różnych istniejących jednostek i poddanie ich obserwacji (ze względu na niewielką liczbę izolowanych żołnierzy rekomendował to ostatnie rozwiązanie) ${ }^{36}$. Gen. Kukiel w pełni podzielił opinię szefa sądownictwa. Informując o sprawie gen. Sosnkowskiego, zauważał jednak, że rozstrzygnięcie sprawy obozu utrudniała postawa władz cywilnych, którym „zdaje się odpowiadać obecny stan rzeczy — ponoszenia pełnej odpowiedzialności za obóz przez wojsko",37.

Zbliżona opinia znalazła się w obszernym referacie poświęconym sprawie obozu w Latrun, przygotowanym w drugiej połowie kwietnia przez Wydział Wywiadu Obronnego MON ${ }^{38}$. Ostrej krytyce poddano w nim działania zarówno dowództwa APW, jak i polskich władz cywilnych na Bliskim Wschodzie: „Okoliczności wśród których doszło do utworzenia obozu w Latrun wskazują, że założenie tego obozu potraktowane być musi jako poważny błąd czynników wojskowych APW, które w pełni ponoszą odpowiedzialność. [...] władze cywilne z dużą giętkością pozbyły się związanego z uciążliwym elementem wśród naszej emigracji wmanewrowując umiejętnie władze wojskowe w taką sytuację, że te zmuszone były do utworzenia obozu, za które władze cywilne nie ponoszą żadnej odpowiedzialności. [...] władze wojskowe poszły zbyt daleko w wyręczaniu władz brytyjskich, które uwolnione zostały od zajmowania się niebezpiecznym elementem polskim, mimo że działo się to na ich terytorium,"39.

\footnotetext{
${ }^{35}$ AAN, MPiOS, t. XCIX, Opinia w sprawie tzw. elementów przestępczych znajdujących się w Palestynie przygotowana przez radcę prawnego M. Litauera, 19 V 1944 r., k. 50-63; AAN, HI-MSZ, mf 175, Notatka „Przestępcy w Palestynie” T. Filipa (MSZ) z 17 IV 1944 r.; mf 175, Opinia „K”, Londyn, 28 VI 1944 r.; mf 175, Pismo A. Wdziękońskiego do H. Strasburgera, b.d. [otrzymane w MSZ 14 VII 1944]. Zob. też: IPMS, PRM, t. CXXVII, Pismo H. Strasburgera do premiera oraz min. sprawiedliwości, spraw wewnętrznych, spraw zagranicznych, pracy i opieki społ., obrony narodowej z $31 \mathrm{~V} 1944 \mathrm{r}$. (Strasburger bronił działań komisji, wskazując na wcześniejsze zaniedbania i brak koordynacji działań oraz powołując się na opinie władz mandatowych). Ostatecznie komisję zlikwidowano już po decyzji o rozwiązaniu obozu w Latrun. Konferencja przedstawicieli ministerstw (28 VII 1944) uznała, że nie ma podstaw prawnych do istnienia komisji, jednak konsul ma prawo do konsultowania się w sprawach przestępczości z delegatami resortów, a także do informowania władz brytyjskich o polskich przestępcach na podstawie zgromadzonej dokumentacji. Zob. AAN, MPiOS, t. XCIX, Protokół z konferencji w sprawie obozu w Latrun 28 VII 1944 r. , k. 101-102.

${ }^{36}$ IPMS, kol. 138/213, Opinia prawna płk. K. Słowikowskiego, szefa Sądownictwa Wojskowego i Naczelnej Prokuratury Wojskowej z 11 III 1944 r.

${ }^{37}$ Ibidem, Depesza gen. M. Kukiela do gen. K. Sosnkowskiego z 12 IV 1944 r.

${ }^{38}$ Ibidem, Referat [Wydziału Wywiadu Obronnego MON] z 21 IV 1944 r. Referat jest anonimowy. Komórkę, która go przygotowała, zidentyfikowano w rezultacie analizy innego dokumentu. Zob. ibidem, Notatka „Opis sprawy Obozu Dyscyplinarnego w Latrun”, Londyn, 14 XII 1944 r. Por. też: ibidem,Wyjaśnienia szefa Sądownictwa Wojskowego w sprawie Obozu Dyscyplinarnego w Latrun przesłane przez płk. dypl. T. Skindera do Wydziału Wywiadu Obronnego MON, b.d.

${ }^{39}$ Ibidem, Referat z 21 IV 1944 r.
} 
W raporcie zwracano także uwagę na negatywne skutki propagandowe funkcjonowania obozu: „Akcja osadzania w obozie ma w dużej mierze pozory zarządzenia antysowieckiego, czego w obecnej sytuacji politycznej winno się unikać, albowiem daje się władzom sowieckim argument propagandowy, że w wojsku polskim poglądy na komunizm są podzielone , a sympatyków komunizmu wielu i tak niebezpiecznych, że zachodzi konieczność izolowania ich w osobnych obozach. Obóz jest zaprzeczeniem głoszonych w armii polskiej haseł demokratycznych, robi wojsku polskiemu złą prasę i złą propagandę, stwarzając pozory, że dyscyplina oparta jest jedynie na terrorze i że wojsko polskie jest ośrodkiem reakcji, o którą posądza się tę część społeczeństwa polskiego, która znalazła się na emigracji "40.

Autor raportu opowiadał się za likwidacją obozu, jednak wskazywał także na zagrożenia związane z taką decyzją: niechętny stosunek władz brytyjskich, zdezawuowanie wobec Brytyjczyków działan dowództwa APW, nasilenie przestępczości po wypuszczeniu ,zintegrowanych" w obozie kryminalistów oraz wykorzystanie ,przez wrogie nam agentury byłych więźniów obozu jako atuty nieprzychylnej propagandy"4".

Negatywne opinie umocniły gen. Sosnkowskiego w przekonaniu, że utworzenie obozu było poważnym błędem. Naczelny Wódz uważał, że jego likwidację należy przeprowadzić we współpracy z władzami brytyjskimi, podkreślając wobec nich zarazem, iż podejmując kontrowersyjną politycznie i prawnie decyzję o utworzeniu miejsca odosobnienia, strona polska chciała ,pójść na rękę” Brytyjczykom. Sosnkowski szczególnie mocno akcentował nasilające się ataki propagandowe wobec Polskich Sił Zbrojnych, w których wykorzystywano także istnienie obozu. W celu uniknięcia kolejnych ataków proponował stopniową likwidację obozu, zarazem sugerując, by zdolnych do służby zwolnionych żołnierzy wcielić do walczącego we Włoszech 2 Korpusu ${ }^{42}$.

W tej sytuacji likwidacja obozu wydawała się przesądzona. Już 3 maja miały miejsce pierwsze zwolnienia osadzonych ,za dobre sprawowanie" ${ }^{43} .21$ maja minister obrony narodowej podpisał wniosek w sprawie rozwiązania obozu, który Rada Ministrów rozpatrywała na posiedzeniu 26 maja. Gen. Kukiel zaproponował, by wszystkich izolowanych cywilów po zwolnieniu przekazać pod opiekę urzędu ministra-delegata do spraw polskich na Wschodzie. Wyjątek stanowić mieli osadzeni w obozie na podstawie decyzji komitetu doradczego przy rządzie palestyńskim, który mieli zostać przekazani władzom brytyjskim. Kukiel wnioskował także, by premier udzielił ministrowi Strasburgerowi szczegółowych instrukcji w kwestii postępowania ze zwolnionymi cywilami, natomiast minister obrony miał wystosować instrukcję dla dowództwa APW w odniesieniu do żołnierzy ${ }^{44}$. Rząd po dyskusji przyjął wniosek ministra Kukiela. Podsumowując sprawę, premier Stanisław Mikołajczyk wyraźnie bronił ministra Strasburgera, twierdząc, że ,zastał ten obóz jako instytucję stworzoną przez władze wojskowe i nie wydaje się być odpowiedzialny za ten stan rzeczy"; szef rządu brał jednak pod uwagę ,ewentualne wyciągnięcie konsekwencji po dokładniejszym zbadaniu sprawy”.45.

\footnotetext{
${ }^{40}$ Ibidem.

${ }^{41}$ Ibidem.

${ }^{42}$ Ibidem, Pismo gen. K. Sosnkowskiego do gen. M. Kukiela z 15 V 1944 r. Na temat obozu w Latrun pisano m.in. w wysokonakładowym dzienniku amerykańskim „Chicago Daily News” (6 V 1944). Zob. ibidem, Notatka „,depesza z Ameryki” z 10 V 1944 r. otrzymana przez Wydział Polityczny MON.

${ }^{43}$ Ibidem, Wyciąg z okresowego meldunku sytuacyjnego Wydziału Informacyjnego Dowództwa APW za maj $1944 \mathrm{r}$.

${ }^{44}$ Protokoty posiedzeń Rady Ministrów Rzeczypospolitej Polskiej, red. nauk. M. Zgórniak, oprac. W. Rojek przy współpracy A. Suchcitza, t. VII (maj-listopad 1944), Kraków 2006 (zał. 251D do protokołu z 26 V 1944), s. 116, 117.

${ }^{45}$ Ibidem (protokół posiedzenia z 26 V 1944), s. 61.
} 
31 maja gen. Kukiel wydał zastępcy dowódcy APW rozkaz „niezwłocznego” rozwiązania obozu, zarazem formułując bardziej szczegółowe wytyczne postępowania wobec zwolnionych. Żołnierze niezdolni do służby mieli być traktowani jako cywile i przekazani pod opiekę polskich władz cywilnych. Oficerów należało przenieść w stan nieczynny lub pozostawić tym stanie ewentualnie urlopować. Podoficerowie i żołnierze mieli zostać przydzieleni do formacji bojowych i poddani obserwacji. Minister zakładał także możliwość utworzenia specjalnego oddziału podległego dowódcy Jednostek Terytorialnych na Środkowym Wschodzie, który miał być wykorzystywany do różnego rodzaju prac bez kontaktu z innymi formacjami. Kukiel podkreślał zarazem, że oddział „nie może mieć charakteru obozu dyscyplinarnego lub izolacyjnego" i powinien opierać się na „silnej i wzorowej kadrze"46.

Z likwidacją obozu nie mógł pogodzić się konsekwentnie broniący jego koncepcji i podkreślający jego rolę gen. Tokarzewski: „O[bóz] D[yscyplinarny] był jedynym ośrodkiem zabezpieczenia przeciw destrukcji kryminalnej i wrogiej nam akcji politycznej na odcinku wojska, a nawet społeczeństwa cywilnego, ro[z]bił robotę ZPP [...] i agentury sowieckiej”. Generał alarmował także, że część izolowanych w obozie to: ,[...] typy aspołeczne, kryminaliści wrogo usposobieni do państwa, element niebezpieczny. W razie nieizolowania ich przez władze cywilne przewiduję nieobliczalne skutki na terenie społeczeństwa palestyńskiego i władz angielskich. [...] Z dotychczasowej praktyki mogę sądzić, że władze cywilne będą dalej bierne w stosunku do elementu kryminalnego"47.

Wydaje się, że w Londynie nie przewidziano wszystkich problemów związanych z likwidacją obozu. Co prawda większość osadzonych została zwolnionych zgodnie z planem (138 osób), jednak definitywne zamknięcie obozu uniemożliwiała sprawa kilkudziesięciu więźniów postrzeganych jako szczególnie niebezpiecznych, a uznanych za niezdolnych do służby wojskowej, a zatem otrzymujących automatycznie status uchodźców cywilnych. Grupa ta liczyła 44 osoby (początkowo brano pod uwagę 52 lub 54 osoby) ${ }^{48}$. Antoni Pająk, tymczasowo kierujący wówczas Delegaturą MPiOS w Jerozolimie, stanowczo sprzeciwił się przejęciu pieczy nad zwolnionymi z Latrun przez aparat opieki społecznej, domagając się ich izolowania przez władze brytyjskie. W tej sytuacji dowództwo APW uzależniało całkowitą likwidację obozu od rozstrzygnięcia sprawy. Warto zauważyć, że problemem okazała się nie tylko kwestia grupy „cywilnej”, gdyż gen. Anders zdecydowanie nie godził się na wcielenie zwolnionych z Latrun żołnierzy do $2 \mathrm{Korpusu}^{49}$. Decydujące znaczenie miało jednak stanowisko wojskowych i cywilnych władz brytyjskich w Palestynie, które zażądały wstrzymania likwidacji obozu. Niektórzy przedstawiciele polskiego rządu brali pod uwagę takie rozwiązania, jak przejęcie obozu przez władze brytyjskie lub stworzenia cywilnego ośrodka odosobnienia w Afryce (w polskich ośrodkach uchodźczych) ${ }^{50}$. Przede wszystkim jednak gabinet

\footnotetext{
${ }^{46}$ Ibidem, Rozkaz gen. M. Kukiela dla gen. M. Tokarzewskiego-Karaszewicza z 31 V 1944 r.

${ }^{47}$ Ibidem, Depesza gen. M. Tokarzewskiego-Karaszewicza do gen. M. Kukiela z 3 VII 1944 r.

${ }^{48}$ Gen. J. Wiatr, generalny kwatermistrz APW, podał dokładne informacje o 201 szeregowych i podoficerach: 138 zwolnionych, 5 niezdolnych do służby (mieli zostać przejęci przez Delegaturę MPiOS), 4 zbiegłych z obozu (12 lipca), oraz 52 niezdolnych do służby i 2 zdolnych do służby ,niebezpiecznych dla otoczenia”. Ibidem, Depesza gen. J. Wiatra dla gen. M. Kukiela z 17 VII 1944 r.

${ }^{49}$ IPMS, PRM, t. CXXVII, Depesza szefa placówki MSW w Jerozolimie C. Andrzejewskiego otrzymana w Londynie 19 VII 1944 r.; IPMS, kol. 138/213, Depesza gen. J. Wiatra do gen. M. Kukiela z 17 VII 1944 r.; AAN, HI-MSZ, mf 490, Depesza od szefa Delegatury MPiOS w Jerozolimie K. Jaroszewskiego dla min. J. Stańczyka z 20 VII 1944 r.

${ }_{50}$ AAN, MPiOS, t. XCIX, Protokół z konferencji w sprawie obozu w Latrun 28 VII 1944 r., k. 100102. Konferencji, z udziałem przedstawicieli ministerstw (urząd ministra-delegata do spraw polskich na Wschodzie, MSW, MON, Ministerstwa Sprawiedliwości, MPiOS, MSZ) przewodniczył dyrektor
} 
Mikołajczyka zdecydowanie podtrzymywał wcześniejszą decyzję o rozwiązaniu obozu ${ }^{51}$. Powstała patowa sytuacja. Nawet w brytyjskich kręgach sztabowych na Bliskim Wschodzie zdawano się odczuwać zażenowanie całą sytuacją. Świadczył o tym fakt, że to właśnie z tych kręgów wyszła dyskretna propozycja, by strona polska nagłośniła brytyjską obstrukcję wobec rozwiązania obozu, w sytuacji gdy za jego dalsze funkcjonowanie część prasy brytyjskiej i amerykańskiej obciążała władze polskie ${ }^{52}$.

Niewątpliwie pod wpływem nieustępliwej postawy strony polskiej wysoki komisarz Palestyny zdecydował się na początku września powiadomić o sprawie rząd brytyjski, uzasadniając niemożność zaakceptowania zwolnienia ostatniej grupy internowanych ${ }^{53}$. Jak zauważała strona polska, sprawa obozu pozostawała jednak nadal $\mathrm{W}$,,martwym punkcie" ${ }^{, 54}$. W tej sytuacji MON zwróciło się do MSZ o interwencję wobec rządu brytyjskiego. 7 października polskie władze otrzymały informację, że urząd wysokiego komisarza Palestyny polecił policji obszaru mandatowego dokładne zbadanie dokumentacji dotyczącej osób pozostających w obozie w Latrun. Strona brytyjska zdecydowała, że osoby uznane na podstawie zebranych dowodów za stanowiące zagrożenie zostaną aresztowane przez władze mandatowe. Pozostali internowani mieli zostać zwolnieni i przejść pod opiekę Delegatury MPiOS. Przewidywano, że liczba zwolnionych, wobec napiętej sytuacji politycznej w Palestynie, będzie znikoma ${ }^{55}$.

Decyzja brytyjska otwierała wreszcie możliwość zakończenia nieznośnie przedłużającej się i bezowocnej rozgrywki wokół obozu w Latrun. Zaistniały warunki do ostatecznego jego zamknięcia, jednak i tym razem nie obeszło się bez problemów.

Zgodnie z decyzją wysokiego komisarza Brytyjczycy przystąpili do rozpatrywania spraw osób przebywających w Latrun, m.in. biorąc pod uwagę charakterystyki internowanych udostępnione przez polskie władze wojskowe. Już po kilku dniach specjalna brytyjska komisja zdecydowała o dalszym internowaniu dziesięciu osób z grupy „cywilnej”, izolowanych

Biura Prezydialnego PRM Adam Romer. Konferencja pokazała pewne różnice zdań między przedstawicielami różnych resortów. Ministerstwo Sprawiedliwości oraz MSW opowiadały się za utworzeniem obozu cywilnego podległego Delegaturze MPiOS. Zob. też IPMS, PRM, t. CXXVII, Notatka J. Jaczynowskiego (ministerstwa sprawiedliwości) z 27 VII 1944 r. Na temat planów przeniesienia zwolnionych do Afryki zob. też: AAN, HI-MSZ, mf 490, Depesza z MSZ (od MPiOS) dla min. H. Strasburgera i konsula A. Wdziękońskiego z 10 VIII 1944 r.

${ }^{51}$ IPMS, kol. 138/213, Depesza gen. J. Wiatra do gen. M. Kukiela z 31 VII 1944 r.; AAN, HI-MSZ, mf 490, Depesza H. Strasburgera do jego zastępcy Józefa Marlewskiego z 1 VIII 1944 r; IPMS, kol. 138/213, Pismo wicepremiera Jana Kwapińskiego do H. Strasburgera z 11 VIII 1944 r.; AAN, HIMSZ, mf 490, Odpis pisma z biura sekretarza rządu palestyńskiego do Dowództwa Jednostek Wojska na Środkowym Wschodzie z 22 VIII 1944 r.; IPMS, kol. 138/213, Zapisek urzędowy z konferencji szefa Wydziału Wywiadu Obronnego MON ppłk. Stanisława Miniewskiego z min. H. Strasburgerem w hotelu „Dorchester” w Londynie 24 VIII 1944 r.; ibidem, Pismo gen. J. Wiatra do min. H. Strasburgera z 29 VIII 1944 r.; ibidem, Pismo gen. M. Kukiela do gen. Tokarzewskiego-Karaszewicza z 30 VIII 1944 r.; ibidem, Pismo gen. M. Tokarzewskiego-Karaszewicza do gen. M. Kukiela z 2 IX 1944 r.

${ }_{52}$ Ibidem, Depesza płk. dypl. A. Szymańskiego dla gen. M. Kukiela z 8 IX 1944 r.

53 AAN, MPiOS, t. XCIX, Pismo ppłk. dypl. S. Miniewskiego do delegata MPiOS w Jerozolimie K. Jaroszewskiego z 10 IX 1944 r., k. 111.

${ }^{54}$ AAN, HI-MSZ, mf 490, Depesza zastępcy ministra-delegata do spraw polskich na Wschodzie Janusza Kruszyńskiego z 19 IX 1944 r.; IPMS, kol. 138/213, Pismo gen. M. Kukiela do min. spraw zagranicznych Tadeusza Romera z 25 IX 1944 r.; ibidem, Pismo ppłk. dypl. S. Miniewskiego do MPiOS z 29 IX $1944 \mathrm{r}$.

${ }_{55}$ AAN, MPiOS, t. XCIX, Pismo kier. Działu Konsularnego MSZ Zdzisława Szczerbińskiego do MPiOS z 7 X 1944 r., k. 112. Zob. też: IPMS, kol. 138/213, Notatka „Opis sprawy Obozu Dyscyplinarnego w Latrun", Londyn, 14 XII 1944 r. 
pod zarzutami kryminalnymi ${ }^{56}$. W połowie grudnia taką samą decyzję podjęto $\mathrm{w}$ sprawie trzydziestu jeden kolejnych osób — byłych żołnierzy zwolnionych z PSZ. Według polskiego dowództwa wojskowego strona brytyjska zajęła takie stanowisko pomimo oświadczenia dowódcy Jednostek Terytorialnych na Środkowym Wschodzie płk. B. Ostrowskiego, który podkreślał, że otrzymał rozkaz zwolnienia wszystkich internowanych. Czterdziestu jeden zatrzymanych zostało osadzonych w brytyjskim obozie Latrun. Podjęli tam oni strajk głodowy, domagając się zwolnienia. Na prośbę uwięzionych interweniował konsul generalny A. Wdziękoński. Jego zastępca konsul Jan Weber udał się do Latrun i rozmawiał z internowanymi. Konsul generalny, który zbadał dostarczone mu przez polskie dowództwo informacje na temat zatrzymanych, doszedł do wniosku, że w wielu wypadkach decyzja o internowaniu nie została dostatecznie uzasadniona, a niekiedy była nawet bezpodstawna. W tej sytuacji minister Strasburger polecił konsulowi wystąpić do władz mandatowych o ponowne rozpatrzenie spraw internowanych ${ }^{57}$.

Spośród czterdziestu jeden internowanych ${ }^{58}$ przez władze brytyjskie trzem osobom zarzucano działalność o charakterze komunistycznym, pozostałych podejrzewano o współpracę z wywiadem niemieckim bądź przestępstwa pospolite (np. afery walutowe), jednak w wielu przypadkach przyczyny izolowania nie były znane władzom polskim ${ }^{59}$.

Decyzja władz brytyjskich o internowaniu omawianej grupy, pomimo kontrowersji, które wywołała, umożliwiła ostateczne zamknięcie sprawy Obozu Dyscyplinarnego w Latrun. 22 I 1945 r., a zatem ponad siedem miesięcy od momentu wydania rozkazu ministra obrony narodowej, gen. Józef Wiatr, ówcześnie pełniący obowiązki dowódcy Jednostek Wojska na Środkowym Wschodzie, mógł powiadomić gen. Kukiela o definitywnej likwidacji obozu ${ }^{60}$.

Powołanie obozu w Latrun było rezultatem złożonego splotu różnych okoliczności i interesów. Niewątpliwie ogromne znaczenie miało tu stanowisko dowództwa APW (3 Korpusu, Jednostek Wojska na Środkowym Wschodzie), a zwłaszcza gen. Tokarzewskiego-Karaszewicza. Generał podkreślał zagrożenie ze strony grup komunistycznych i prosowieckich i opowiadał się za zdecydowanymi działaniami, obawiając się destrukcyjnego wpływu

\footnotetext{
${ }^{56}$ AAN, HI-MSZ, mf 490, Pismo A. Wdziękońskiego do MSZ z 18 X 1944 r.

${ }^{57}$ Ibidem, mf 319, Depesza A. Wdziękońskiego z 30 XII 1944 r.; ibidem, mf 490, Pismo A. Wdziękońskiego do MSZ z 2 I 1945 r.; ibidem, mf 331, Depesza A. Wdziękońskiego z 17 I 1945 r. Wdziękoński proponował także powołanie specjalnej polskiej komisji z udziałem przedstawicieli wojska, która miała badać sprawy internowanych.

${ }^{58}$ Analiza materiałów źródłowych może nasuwać pewne wątpliwości co do liczby internowanych. W wielu cytowanych wcześniej dokumentach wspomina się o trzydziestu jeden zatrzymanych. Wynika to $\mathrm{z}$ faktu, że należeli oni do wspomnianej grupy czterdziestu czterech osób zatrzymanych w Latrun po decyzji o likwidacji obozu z 31 V 1944 r. W wyniku zgody władz brytyjskich na likwidację obozu (październik 1944 r.) zwolniono z tej grupy trzynascie osób (w tym jedną wcielono do wojska). Zob. AAN, HI-MSZ, mf 490, Pismo A. Wdziękońskiego do MSZ z 2 I 1945 r.; IPMS, A 6/1, Sprawozdanie szefa Wydziału Wojskowego Urzędu Ministra-Delegata do Spraw Polskich na Wschodzie płk. dypl. Tadeusza Machalskiego dla min. obrony narodowej i szefa Sztabu Naczelnego Wodza z 27 II 1945 r. Polskie sprawozdania na ogół nie uwzględniały natomiast dziesięciu osób z grupy „cywilnej”, która była traktowana oddzielnie. Łączną liczbę czterdziestu jeden internowanych potwierdza: AAN, HI-MSZ, mf 490, Wykaz internowanych przez władze brytyjskie po likwidacji polskiego obozu w Latrun przesłany przez gen. M. Kukiela do MSZ 26 II 1945 r.

${ }^{59}$ Ibidem. Można domniemywać, że większość osób, których powody internowania nie były znane władzom polskim (najczęściej występują tu żydowsko brzmiące nazwiska), była izolowana pod zarzutem związków z działalnością zbrojną organizacji żydowskich w Palestynie.

${ }^{60}$ AAN, HI-MSZ, mf 490, Depesza z Kairu od gen. J. Wiatra dla gen. M. Kukiela z 22 I 1945 r.
} 
tych środowisk na wojsko ${ }^{61}$. Z kolei przedstawiciele polskich władz cywilnych na Bliskim Wschodzie niepokoili się przede wszystkim narastającymi przejawami przestępczości pospolitej wśród części byłych żołnierzy, najczęściej o kryminalnej przeszłości. Obawiano się, że mogą oni kompromitować Polskę na terenie Palestyny, gdzie istniał także „wrażliwy” aspekt stosunków polsko-żydowskich (pogarszających się m.in. na tle sprawy dezercji Żydów z APW). Władze cywilne nie chciały także obciążać aparatu opieki społecznej „elementem kryminalnym", nie tylko obawiając się o bezpieczeństwo uchodźców, lecz także biorąc pod uwagę ich reakcję. Chociaż władze cywilne na Bliskim Wschodzie i dowództwo APW rzadko znajdowały wówczas wspólny język, w tej kontrowersyjnej sprawie zajęły zasadniczo zgodne stanowisko. Zupełnie inaczej widziano tę sprawę w Londynie. Zarówno Naczelny Wódz, jak i przedstawiciele rządu, a zwłaszcza minister obrony narodowej, zajęli zdecydowanie krytyczne stanowisko wobec utworzenia obozu. Wydano druzgocące opinie prawne, jak i wskazano na negatywne reperkusje propagandowe.

Należy wreszcie podkreślić rolę w całej sprawie cywilnych i wojskowych władz brytyjskich w Palestynie. Brytyjczycy, chociaż zwalczanie przestępczości leżało w kompetencjach władz mandatowych, wyraźnie dążyli do obarczenia strony polskiej odpowiedzialnością za izolację osób niebezpiecznych z ich punktu widzenia. Strona brytyjska nie tylko wyraźnie inspirowała utworzenie obozu, ale także przez ponad pół roku uniemożliwiała jego likwidację, co stawiało polskie władze w niemal żenującej sytuacji.

\section{"The Elimination from the Ranks of a Troublesome and Dangerous Element". The Disciplinary Camp of the Polish Army in the East in Latrun (Palestine, 1944-1945)}

The question of a detention camp in Latrun (Palestine) remains an almost unknown episode in the history of the Polish Armed Forces in the Middle East during the Second World War. The camp was established at the beginning of 1944 for the purpose of isolating officers and soldiers suspected of communist and pro-Soviet activity as well as men regarded as dangerous common criminals. The camp inmates included also several score civilians, former soldiers accused by the British authorities of assorted crimes and felonies. The creation of the camp met with a negative reaction on the part of the Polish civilian and military authorities in London. Prepared legal opinions clearly indicated the absence of legal foundations for the establishment of a detention camp. It was also indicated that the opening of the camp was used for propaganda attacks launched by part of the press in Great Britain and the USA, aimed at the Polish authorities in exile as well as the Polish Armed Forces. The retention of the camp was supported primarily by the Polish military command in the Middle East, which intended to isolate a group of soldiers representing pro-Soviet attitudes, and by Polish civilian authorities in the Middle East, fearing an intensification of common crime. With the support of the Government of the Republic of Poland and the Commander-in-Chief, the Minister of National Defence ordered the closure of the camp (31 May 1944). This did not take place, however, because for several months the British authorities in Palestine did not consent to the discharge of several score inmates. The British obviously planned to encumber the Polish side with responsibility for the isolation of persons whom they regarded as dangerous. The British side actually inspired the creation of the camp, and for another half a year made it impossible to close it, thus putting the Polish side in a very awkward situation. Ultimately, the camp ceased functioning in January 1945.

\footnotetext{
${ }^{61}$ Wydaje się, że obawy związane z działalnością komunistów wśród żołnierzy i uchodźców były jednak przesadzone. Chociaż aktywność komunistów w Palestynie w latach 1944-1945 wyraźnie wzrastała, polska emigracja wojenna, mająca w większości tragiczne doświadczenia w Sowietach, pozostawała „odporna” wobec tego typu agitacji. Zob.: J. Pietrzak, Polscy uchodźcy..., s. 393-410.
} 